\title{
Bioaccumulation of Mercury and Selenium in Trichiurus lepturus
}

\author{
Tércia G. Seixas, ${ }^{* a}$ Isabel Moreira, ${ }^{a}$ Olaf Malm ${ }^{b}$ and Helena A. Kehrig ${ }^{b}$ \\ ${ }^{a}$ Departamento de Química, Pontifícia Universidade Católica do Rio de Janeiro, \\ 22453-900 Rio de Janeiro-RJ, Brazil \\ ${ }^{b}$ Laboratório de Radioisótopos Eduardo Penna Franca, IBCCF, \\ Universidade Federal do Rio de Janeiro, 21941-902 Rio de Janeiro-RJ, Brazil
}

\begin{abstract}
Mercúrio e selênio foram determinados no tecido muscular do peixe espada (Trichiurus lepturus) de três áreas costeiras (Baía da Ilha Grande, Baía de Guanabara and Búzios, Estado do Rio de Janeiro) que apresentam diferentes condições ambientais, localizadas no sudeste brasileiro. Hg foi determinado por espectrometria de absorção atômica em vapor frio (CV-AAS) e Se por espectrometria de absorção atômica com forno de grafite (GF-AAS). As concentrações variaram de 0,44 a $0,87 \mu \mathrm{g} \mathrm{Hg} \mathrm{g}^{-1}$ e de

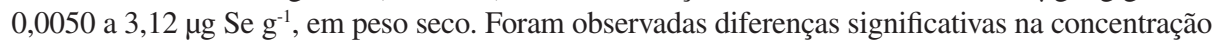
de mercúrio e na razão molar selênio:mercúrio entre as áreas. O comprimento total e os intervalos de tamanho influenciaram na acumulação de mercúrio, entretanto estes parâmetros biológicos não influenciaram na acumulação de selênio. Foi observado um excesso de selênio em relação ao mercúrio. Provavelmente, as diferenças regionais podem ser em parte atribuídas às diferenças nas condições ambientais (temperatura da água e produção primária), e também a outros fatores, tais como a escolha das presas e a disponibilidade destes elementos nos ambientes.
\end{abstract}

Mercury and selenium were assessed in the muscle tissue of cutlassfish (Trichiurus lepturus) from three coastal areas (Ilha Grande Bay, Guanabara Bay and Búzios coast, Rio de Janeiro State, Brazil) that present different environmental conditions, localized in Southeastern Brazil. Hg was determined by cold vapor atomic absorption spectrometry (CV-AAS) and Se was determined by graphite furnace atomic absorption spectrometry (GF-AAS). Across sites, mercury and selenium

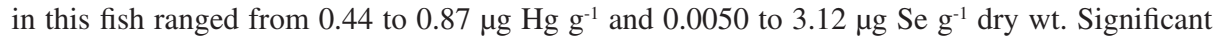
differences were observed in mercury concentrations and $\mathrm{Se}: \mathrm{Hg}$ molar ratios among the areas. The total length and size intervals presented a significant influence on the accumulation of mercury, whereas this pattern was not observed for selenium. A large excess of selenium in relation to mercury was observed. Probably, the regional differences can be partly attributed to differences in the prevalent environmental conditions (water temperature and primary production), and also to other factors, such as prey choices and availability across locations.

Keywords: cutlassfish, trace elements, Se:Hg molar ratio, environmental conditions, South Atlantic Ocean

\section{Introduction}

The presence and behavior of mercury in aquatic systems are of great interest and importance since mercury is the only heavy metal which bioaccumulates and biomagnifies through the aquatic food web ${ }^{1}$ affecting productivity, reproduction and survival of aquatic organisms, and can, eventually, be hazardous to humans. ${ }^{2}$

Selenium is recognized as an essential micronutrient for animals, active in the activities of enzymes, acting as a

*e-mail: terciaguedes@gmail.com protective agent against the toxicity of mercury in the form of methylmercury. ${ }^{3,4}$ One of the most important study about mercury and selenium in marine fish found that ca. 1:1 molar ratio of $\mathrm{Se}: \mathrm{Hg}$ in tuna fish reduced the toxic effects of methylmercury. ${ }^{5}$

Mercury and selenium in fish tissues are expected to vary in a wide range of concentration, reflecting feeding behavior and exposure to environmental levels. ${ }^{6}$ However, mercury and selenium contents in fish greatly vary among species from the same location. Mercury and selenium concentrations in muscle tissue are controlled by the dietary habits and size of an organism, the physical and 
chemical characteristics of the system they inhabit, and the magnitude of human activities in the catchment. ${ }^{\text {? }}$

Limited information is available on the mercury and selenium burden of tropical biota found in Southern Hemisphere waters. In the South Atlantic Ocean, several studies have reported mercury and selenium concentrations in marine organisms, ${ }^{8,9}$ but information about selenium in top-predator fish is still scarce. ${ }^{10,11}$ Furthermore, tropical coastal waters are less monitored than marine environments in the Temperate and Polar Regions, in particular the South Atlantic Ocean, which is often considered less contaminated then the Northern ocean.

Trichiurus lepturus (Linnaeus, 1758), known as cutlassfish, is a carnivorous marine fish that occurs along the whole tropical and sub-tropical latitude belt, including the Western Atlantic Ocean. ${ }^{12}$ It has demersalpelagic habits and can be considered a voracious predator, a concern regarding food supplies..$^{13}$ According to Martins et al.,${ }^{14}$ the specimens from the South Brazil can be grouped by total length (L) into different life phases. Each life phase presents differences: 'juveniles' (no gonadal development, $50<\mathrm{L}<300 \mathrm{~mm}$ ), 'sub-adults' (initial gonadal development, $300<\mathrm{L}<700 \mathrm{~mm}$ ), 'small adults' (mature, $700<\mathrm{L}<1,000 \mathrm{~mm}$ ) and 'large adults' $\mathrm{L}>1,000 \mathrm{~mm}) .{ }^{14}$ Previous studies with adult specimens of T. lepturus $(\mathrm{L}>1,000 \mathrm{~mm})$ in Northern Rio de Janeiro showed that in this region, the diet of cutlassfish was composed of pelagic and demersal prey species, including co-specifics, associated with estuarine and coastal areas. ${ }^{15}$ Some fish species and crustacean species were the most representative items in its diet. ${ }^{13}$

There is a need for a basin-wide and systematic approach to sampling and analysis of mercury and selenium in fish from different tropical areas. This means selecting species that are representative of the location from which they are captured. The present study makes an initial contribution to this task by presenting mercury and selenium data from three different areas along the Rio de Janeiro State (Southeastern Brazilian coast). For this purpose, a predatory fish, cutlassfish in different life phases (size intervals) was sampled in three coastal ecosystems with different degradation levels and environmental conditions (Ilha Grande Bay, Guanabara Bay and Búzios coast) (Figure S1, Supplementary Information (SI) section). Finally, we aimed to evaluate and compare the sampling areas according to the mercury, selenium and Se:Hg molar ratios in fish.

Thus, the present study tested whether environmental conditions and biological characteristics influence the assimilation of mercury and selenium in the muscle tissue of a top-predator fish, T. lepturus.

\section{Experimental}

\section{Sampling areas}

The Ilha Grande Bay (total area: 3,100 km², 22 ${ }^{\circ} 50$ 'S and $23^{\circ} 20^{\prime} \mathrm{S}$ ) is a complex estuarine system situated in the Southern coast of the Rio de Janeiro State (Figure S1). It is a very important water body concerning economic and ecological purposes since it has an important commercial harbor, an oil terminal, many industries and two nuclear power plants. Despite the presence of these potential pollution sources, this bay can be considered a non-contaminated area, since low levels of metals such as $\mathrm{Ni}, \mathrm{Cu}, \mathrm{Cr}, \mathrm{Mn}$, $\mathrm{Zn}$ and $\mathrm{Hg}$ have been found in sediments ${ }^{16}$ and fish. ${ }^{17}$ Among the sampling areas considered in the present study, Ilha Grande Bay presents the most preserved ecosystem and is considered to be a biodiversity hotspot and includes a high number of protected areas. ${ }^{18}$

The Guanabara Bay (total area: $384 \mathrm{~km}^{2}, 22^{\circ} 40^{\prime} \mathrm{S}$ and $23^{\circ} 00^{\prime} \mathrm{S}$ ) is the most important estuary for fish production on the Southeastern Brazilian coast (Figure S1). ${ }^{19}$ Guanabara Bay presents the most degraded ecosystem and also, is the most studied area in the Brazilian coast. ${ }^{20}$ This area receives impacts in the form of domestic sewage and untreated industrial effluents from a densely populated area with over 10,000 industries, besides a very active port and a complex petrochemical pole. ${ }^{19}$ An important mercury source in this bay is a chlor-alkali plant, located in the most polluted area of the bay's drainage basin, in the Northwest portion of this aquatic system. Changes in the bay's drainage areas, beginning in the early nineteenth century, have continued to cause severe environmental degradation. Consequently, the bay presents high concentrations of toxic metals and hydrocarbons in sediments, and changes in the pelagic and benthic communities. ${ }^{21}$

The coastal region of Búzios is located on the North coast of Rio de Janeiro State $\left(22^{\circ} 44^{\prime} \mathrm{S}, 41^{\circ} 52^{\prime} \mathrm{W}\right.$, Figure S1) and is characterized by upwelling events driven by the wind ${ }^{22,23}$ that induces a particularly dry climate. ${ }^{24}$ This region presents a totally different climatic regime when compared to Guanabara Bay and Ilha Grande Bay and also, is known for its elevated marine productivity due to the seasonal upwelling phenomenon. ${ }^{25}$ Coastal upwelling is an important process because it brings nutrient-rich water to the surface, thereby allowing the development of phytoplankton blooms. ${ }^{23,26}$ Acoording to Carbonel and Valentin, ${ }^{27}$ the sea surface temperature that normally ranges from 20 to $22^{\circ} \mathrm{C}$ may decrease to $15^{\circ} \mathrm{C}$, triggering an enrichment in nutrient concentration of up to $10-12 \mu \mathrm{mol} \mathrm{L} \mathrm{L}^{-1} \mathrm{NO}_{3}-\mathrm{N}$ and a phytoplankton production (in chlorophyll $a$ ) of up to $6 \mathrm{mg} \mathrm{L}^{-1}$. 
In order to evaluate the trophic stage of Ilha Grande Bay, Guanabara Bay and Búzios coast aquatic ecosystems, the concentration of chlorophyll $a$ was determined in the superficial water layer (depth of 0.2-1.0 m) from the three areas. Water samples were collected according to US EPA (US Environmental Protection Agency) method 1699. ${ }^{28}$ Surface salinity and $\mathrm{pH}$ were measured with a salinometer and a $\mathrm{pH}$ meter (Table 1). Sampling was performed at neap tide cycle during the day at different points inside the bays. In the laboratory, water were filtered through $0.45 \mu \mathrm{m}$ glass fiber filters (Milipore), using a vacuum pump. Two filters were collected per sample. These filters were sheltered from light until extraction and chlorophyll $a$ analysis. After extraction in $90 \%$ acetone for $18 \mathrm{~h}$ at $4{ }^{\circ} \mathrm{C}$, the chlorophyll $a$ concentrations were fluorometrically determined using a fluorescence spectrophotometer as described by Parsons et al. ${ }^{29}$

A total of 64 specimens of T. lepturus with different total lengths (L) were bought from local fishermen, between 2009 and 2010. After sampling, the biological characteristics of each individual were obtained, and sub-samples of dorso-lateral muscle were removed, according to FAO (Food and Agriculture Organization) recommendations. ${ }^{30}$ The specimens presented the total length varying from $844-1,300 \mathrm{~mm}$ (mean of 1,005 $\pm 122 \mathrm{~mm}$ ), $622-1,230 \mathrm{~mm}$ (mean of $875 \pm 192 \mathrm{~mm}$ ) and 810-1,030 mm (mean of $955 \pm 61 \mathrm{~mm}$ ) for Ilha Grande Bay, Guanabara Bay and Búzios coast, respectively. The large adult $(\mathrm{L}>1,000 \mathrm{~mm})$ specimens were captured by gillnet fisheries, as this species is one of the targets of this type of capture, whereas sub-adult $(300<\mathrm{L}<700 \mathrm{~mm})$ and small adult $(700<\mathrm{L}<1,000 \mathrm{~mm})$ specimens were accidentally captured by trawl nets, during commercial shrimp and sciaenidae fish species captures. All samples taken were freeze-dried and sheltered from light until analysis. After the procedure of lyophilization, the muscle samples lost around $75 \%$ of their water content.

\section{Instrumentation}

Muscle tissue was analyzed for total mercury by a cold vapor atomic absorption spectrometer (CV-AAS) with a flow injection mercury system (FIMS) FIAS 400 (Perkin Elmer) with auto sampler AS90 (Perkin Elmer). The carrier gas was argon (99.999\%) at a flow rate of

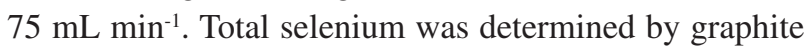
furnace atomic absorption spectrometry (GF-AAS), using an Analytik Jena spectrometer ZEEnit 60 (Jena, Germany) equipped with Zeeman-effect background correction and auto sampler MPE-52 (Analytik Jena). Integrated contact tubes with PIN platforms (Analytik Jena, part No. 407-152.011) were also used. The protective and carrier gas was argon (99.999\%, Aga, Rio de Janeiro, Brazil) at a flow rate of $2 \mathrm{~L} \mathrm{~h}^{-1}$. The operating parameters and the instrumental settings were adjusted according to the manufacturer's recommendations, unless otherwise specified. All measurements were based on integrated absorbance, with a $5 \mathrm{~s}$ integration time.

\section{Analytical procedure}

For mercury determination, dried muscle samples $(0.05 \mathrm{~g})$ were acid digested with $\mathrm{H}_{2} \mathrm{SO}_{4}: \mathrm{HNO}_{3}$ and concentrated $\mathrm{H}_{2} \mathrm{O}_{2}$ in a centrifuge tube at $60^{\circ} \mathrm{C}$ in water bath. Mercury concentrations in the acid digested solution were determined by CV-AAS (FIMS-system) with $\mathrm{NaBH}_{4}$ as a reducing agent. A detailed description of the method used is given elsewhere. ${ }^{31}$ For selenium determination, dried muscle samples were acid digested with nitric acid in a screw-capped vessel. The vessel was then heated to $60^{\circ} \mathrm{C}$ in a water bath. Selenium concentrations in the acid digested solution were determined by GF-AAS. Palladium nitrate was used as a chemical modifier. A detailed description of the method used is given elsewhere. ${ }^{32}$ The limits of detection were 0.05 and $0.80 \mu \mathrm{g} \mathrm{L}^{-1}$ for mercury and selenium, respectively.

Quality control was performed by a strict blank control, the analysis of replicates and certified reference materials. Accuracy was assessed through the analysis of certified material from the National Research Council-Canada (DORM-2). Results for mercury DORM-2 $(\mathrm{n}=10)$ and selenium DORM-2 $(\mathrm{n}=10)$ were $4.60 \pm 0.54$ and $1.34 \pm 0.19 \mu \mathrm{g} \mathrm{g}^{-1}$, whereas the CRM (certified reference material) has a certified mercury value of $4.64 \pm 0.26$ and $1.40 \pm 0.09 \mu \mathrm{g} \mathrm{g}^{-1}$, respectively. Average recovery values

Table 1. Some physical and chemical parameters of the water from Ilha Grande Bay, Guanabara Bay and Búzios coast, at the moment of water sampling

\begin{tabular}{lccc}
\hline & Ilha Grande Bay & Guanabara Bay & Búzios coast \\
\hline Date of sampling & May 23-24, 2011 & May 11, 2011 & May 2, 2011 \\
Number of sampling points & 6 & 5 & 2 \\
Salinity (min-max) & $(30.0-35.0)$ & $(31.4-33.7)$ & $(35.5-36.0)$ \\
$\mathrm{pH}(\min -\max )$ & $(6.9-8.1)$ & $(8.0-8.2)$ & - \\
Total chlorophyll $a /(\mu \mathrm{g} \mathrm{L}-1)(\min -\max )$ & $(0.5-1.9)$ & $(6.6-27.2)$ & $(0.5-1.2)$ \\
\hline
\end{tabular}


were always $\geq 90 \%$ of the certified values. Reproducibility was evaluated using the coefficient of variation of the replicates, being always less than $15 \%$.

\section{Statistical analysis}

Statistical analyses were performed using Statistica ${ }^{\circledR} 7.0$ for Windows (StatSoft, Inc. 1984-2004, USA). After verification of the non-normal distribution of each data set, an analysis of variance was done by Kruskal-Wallis ANOVA to compare the concentrations of mercury, selenium and and $\mathrm{Se}: \mathrm{Hg}$ molar ratios in muscle tissue of cutlassfish from the three regions. A linear regression was performed to determine the relationship between the biological parameters (total length, L) and the concentrations of mercury and selenium in muscle tissue and also, to evaluate the differences in the rates of trace element accumulation, when a logarithmic element concentration was related to T. lepturus length. A $p$ value of less than 0.05 was chosen to indicate statistical significance. Values are presented as mean \pm standard deviation (SD) and range (min-max), based on a dry weight basis (dry wt.).

\section{Results and Discussion}

According to Håkanson, ${ }^{33}$ the concentration of chlorophyll $a$ in the superficial water layer (depth of 0.2-1.0 m) indicated that the aquatic environments were typically eutrophic for Guanabara Bay and oligotrophic for Ilha Grande Bay and Búzios coast (Table 1) at the moment of the water sampling. Previous studies reported that the trophic stage of Guanabara Bay varies from eutrophic to hypereutrophic. ${ }^{21,34}$ The upwelling ecosystem at Búzios coast is extremely sensitive to wind changes with nutrient-rich water reaching the surface under NE winds along a coastal belt less than $5 \mathrm{~km}$ wide. In the Cabo Frio (Rio de Janeiro State) upwelling, which is the same event that occurred in Búzios, chlorophyll values ranged from approximately $0.5-2.0 \mathrm{mg} \mathrm{L}^{-1} .35$

The range and mean concentrations, on a dry weight basis, of mercury and selenium $\left(\mu \mathrm{g} \mathrm{g}^{-1}\right)$ and the ratios of molar concentrations of selenium to mercury in the muscle tissue of cutlassfish, as well as the size fish intervals are summarized in Table 2. Our results were of the same order of magnitude as those reported in earlier studies with this fish species from the South America coastal regions (Table 2). Some of our data

Table 2. Mean and range mercury $(\mathrm{Hg})$ and selenium (Se) concentrations ( $\mu \mathrm{g} \mathrm{g}^{-1}$ dry wt.) in muscle tissue of Trichiurus lepturus collected from some regions of South America, the ratios of molar concentrations of selenium to mercury, as well as the respective biological parameters and size intervals

\begin{tabular}{|c|c|c|c|c|c|c|c|}
\hline $\begin{array}{l}\text { Total length / } \\
\mathrm{mm}\end{array}$ & Size intervals & $\mathrm{N}$ & $\mathrm{Hg}$ & $\mathrm{Se}$ & $\begin{array}{c}\mathrm{Se}: \mathrm{Hg} \\
\text { molar ratios }\end{array}$ & Location & Ref. \\
\hline $\begin{array}{l}700-1,000 \\
1,015-1,300\end{array}$ & $\begin{array}{l}\text { small adult } \\
\text { large adult } \\
\text { mean } \\
\text { range }\end{array}$ & $\begin{array}{c}13 \\
8\end{array}$ & $\begin{array}{c}0.29 \pm 0.08 \\
0.44 \pm 0.23^{\mathrm{a}} \\
0.35 \pm 0.16 \\
0.23-0.87\end{array}$ & $\begin{array}{l}0.78 \pm 0.49 \\
1.27 \pm 1.09 \\
0.96 \pm 0.78 \\
0.0005-3.12\end{array}$ & $\begin{array}{l}6.78 \pm 4.32 \\
9.82 \pm 8.73 \\
7.52 \pm 6.78 \\
0.005-29.7\end{array}$ & IB & $\mathrm{b}$ \\
\hline $\begin{array}{l}620-690 \\
710-1,000 \\
1,045-1,380\end{array}$ & $\begin{array}{l}\text { sub-adult } \\
\text { small adult } \\
\text { large adult } \\
\text { mean } \\
\text { range }\end{array}$ & $\begin{array}{c}4 \\
18 \\
8\end{array}$ & $\begin{array}{c}0.20 \pm 0.03 \\
0.25 \pm 0.06 \\
0.50 \pm 0.21^{\mathrm{a}} \\
0.30 \pm 0.15 \\
0.15-0.81\end{array}$ & $\begin{array}{c}1.10 \pm 0.20 \\
0.94 \pm 0.05 \\
0.94 \pm 0.12 \\
1.01 \pm 0.17 \\
0.77-1.36\end{array}$ & $\begin{array}{l}7.55 \pm 1.43 \\
7.57 \pm 5.10 \\
1.23 \pm 0.66 \\
5.32 \pm 3.74 \\
0.71-13.75\end{array}$ & GB & b \\
\hline $\begin{array}{l}810-1,000 \\
1,010-1,030\end{array}$ & $\begin{array}{l}\text { small adult } \\
\text { large adult } \\
\text { mean } \\
\text { range }\end{array}$ & $\begin{array}{c}12 \\
3\end{array}$ & $\begin{array}{c}0.12 \pm 0.09 \\
0.13 \pm 0.09 \\
0.13 \pm 0.08 \\
0.04-0.37\end{array}$ & $\begin{array}{c}0.93 \pm 0.57 \\
0.71 \pm 0.51 \\
0.88 \pm 0.55 \\
0.38-2.35\end{array}$ & $\begin{array}{c}24.05 \pm 16.25 \\
16.25 \pm 9.56 \\
22.49 \pm 15.19 \\
6.50-59.90\end{array}$ & $\mathrm{BC}$ & b \\
\hline $1,148 \pm 59$ & & 2 & $0.62 \pm 0.28$ & - & - & $S$ & 36 \\
\hline $631 \pm 101$ & & 104 & $0.50 \pm 0.25$ & - & - & NB & 12,37 \\
\hline $450-1,500$ & & 17 & $1.07 \pm 1.06$ & - & - & NR & 11 \\
\hline $637 \pm 175$ & & 12 & $0.53 \pm 0.45$ & - & - & NR & 38 \\
\hline $1,410 \pm 62$ & & 12 & $1.35 \pm 0.90$ & - & - & NR & 39 \\
\hline $620-1,380$ & & 28 & $0.31 \pm 0.16$ & - & - & GB & 40 \\
\hline $620-1,200$ & & 18 & $0.77 \pm 0.37$ & - & - & GB & 41 \\
\hline- & & 5 & $0.09 \pm 0.07$ & - & - & IB & 42 \\
\hline - & & 6 & $0.14 \pm 0.04$ & - & - & IB & 42 \\
\hline
\end{tabular}

${ }^{a}$ Significant higher $(p<0.05)$ than other size intervals; bthis study; IB: Ilha Grande Bay, GB: Guanabara Bay, BC: Búzios coast, S: Suriname, NB: Northeastern Brazil and NR: North Rio de Janeiro; Ref.: references. 
were lower than those found in cutlassfish from Suriname, ${ }^{36}$ Northeastern Brazil, ${ }^{12,37}$ North Rio de Janeiro ${ }^{11,38,39}$ and also Guanabara Bay ${ }^{40,41}$ (Table 2). However, it is difficult to compare data for mercury and selenium in species that live in different environments since the prevalent environmental conditions (water temperature and primary production) and also other factors, such as the level of food contamination, can influence on trace elements accumulation. In the South America, few studies have been reported mercury and selenium concentrations in cutlassfish. Most of them have limited number of individuals and life span (Table 2). In the Brazilian coast, Guanabara Bay is the most studied area regarding mercury and selenium concentrations in this fish species (Table 2). However, little information is available regarding mercury and mainly selenium concentrations in cutlassfish from Ilha Grande Bay (Table 2).

Amongst the data generated as part of the present study (Table 2), all samples presented muscular mercury concentrations lower than maximum permissible limit of $1.00 \mu \mathrm{g} \mathrm{g} \mathrm{g}^{-1}$ wet wt. established for human consumption of predatory fish in Brazil..$^{43}$ The muscle samples of cutlassfish presented mercury concentrations ranged from 0.01 to $0.22 \mu \mathrm{g} \mathrm{g}^{-1}$ wet wt. (or from 0.04 to $0.87 \mu \mathrm{g} \mathrm{g}^{-1}$ dry wt.). These results were also below the maximum permissible limit established for food by the World Health Organization (WHO, $0.50 \mu \mathrm{g} \mathrm{g}^{-1}$ wet wt.). ${ }^{2}$ All samples evaluated presented selenium concentration in muscle below the maximum allowable selenium concentrations, $2.00 \mu \mathrm{g} \mathrm{g}^{-1}$ wet wt., proposed by Lemly. ${ }^{44}$ The muscle samples of cutlassfish presented selenium concentrations ranged from 0.0001 to $0.78 \mu \mathrm{g} \mathrm{g}^{-1}$ wet wt. (or from 0.0005 to $3.12 \mu \mathrm{g} \mathrm{g}^{-1}$ dry wt.). This mean that there is no risk to human health since all samples can be considered suitable for consumption.

No significant difference $(p>0.05)$ in total length (L) was found between the specimens from the three sampling areas, suggesting that both groups are equally represented in the sampled groups, making possible to directly compare inter-site differences regarding mercury and selenium concentrations. However, despite the fact that fish collected at both areas presented similar L, they are not necessarily of the same size intervals. The specimens from Ilha Grande Bay and Búzios coast were in two different size intervals (large adult and small adult) while the specimens from Guanabara Bay were constituted by three different size intervals (large adult, small adult and sub-adult).

\section{Effect of total length and/or size intervals on the accumulation of mercury and selenium}

Data analysis showed that the size intervals and/or total length seem to influence mercury muscle accumulation in fish specimens collected at Ilha Grande Bay and Guanabara Bay since the large adult specimens presented the highest and most significant mercury concentrations in both areas. T. lepturus from these areas presented similar selenium concentrations and the size intervals and/or total length presented no significant influence on selenium accumulation by the specimens (Table 2).

The positive correlation found between muscular mercury concentrations and total length of cutlassfish is in accordance to other studies conducted with estuarine and marine fish species..$^{10,12,17,37}$ The ongoing accumulation can be explained by the fact that methylmercury, which constitutes the major fraction of mercury in the muscle of predatory fish, strongly binds to thiol groups of proteins whose content increases with length. ${ }^{45}$ In general, the adult specimens of top-predators fish present the highest muscular mercury concentrations as a consequence of the process of methylmercury biomagnification along the aquatic food web. ${ }^{41}$ The trophic transfer of trace elements from prey to predator has been recognized as an important route for the incorporation and bioaccumulation of mercury and selenium by aquatic animals. ${ }^{46}$

A weak and positive correlation was found between selenium concentrations in muscle tissue and length of T. lepturus from Ilha Grande Bay $(\mathrm{R}=0.16 ; p>0.05)$. More weak and negative correlations were found between selenium concentrations in muscle tissue and total length of T. lepturus from Guanabara Bay $(\mathrm{R}=-0.35 ; p>0.05)$ and Búzios coast $(\mathrm{R}=-0.06 ; p>0.05)$, indicating that the accumulation of selenium in this fish species did not necessarily take place with the increase in total length, as in the case of mercury. A similar pattern was observed by Branco et al..$^{10}$ in predatory fish species (swordfish and blue shark) from two areas in the North Atlantic Ocean, where samples collected close to the line of Equator presented negative correlations between muscular selenium and total length.

The negative trend found between selenium concentrations in muscle tissue and total length of cutlassfish from Guanabara Bay and Búzios coast suggests that the initial life phase of this fish species was probably more exposed to selenium from detritus and sediment ${ }^{47}$ since cutlassfish preferential prey in this life stage are benthic organisms. ${ }^{14}$ The dietary exposure of fish to selenium is usually the dominant pathway of uptake of this element. ${ }^{49}$ Selenium has the propensity to bioaccumulate within the base of food webs: from water and sediment to aquatic plants and invertebrates, and finally, to fish. ${ }^{48}$ However, in aquatic ecosystems, sediments and organic detritus could be an extremely important pathway of selenium contamination to benthic organism that, in 
turn, can become a source selenium for accumulation by predatory fish. ${ }^{11}$

\section{Regional differences regarding mercury and selenium accumulations}

In this study, significant regional differences $(p<0.05)$ were observed regarding mercury accumulation in cutlassfish. In general, specimens of T. lepturus collected in Ilha Grande Bay $\left(0.35 \pm 0.16 \mu \mathrm{g} \mathrm{g}^{-1}\right.$ dry wt. $)$ presented the highest mercury concentrations, followed by Guanabara Bay $\left(0.30 \pm 0.15 \mu \mathrm{g} \mathrm{g}^{-1}\right.$ dry wt. $)$ and Búzios coast $\left(0.12 \pm 0.08 \mu \mathrm{g} \mathrm{g}^{-1}\right.$ dry wt.). However, the mean selenium concentrations found in the muscle tissue of cutlassfish from these areas can be considered similar since no significant difference was observed among them: Ilha Grande Bay $\left(0.96 \pm 0.78 \mu \mathrm{g} \mathrm{g}^{-1}\right.$ dry wt. $)$, Guanabara Bay $\left(1.01 \pm 0.17 \mu \mathrm{g} \mathrm{g}^{-1}\right.$ dry wt.) and Búzios coast $\left(0.88 \pm 0.54 \mu \mathrm{g} \mathrm{g}^{-1}\right.$ dry wt. $)$.

The lowest mercury concentrations found in cutlassfish from Búzios coast can be explained by the upwelling events that occur in this area. According to Bargagli et al.,$^{50}$ the low temperature of the marine coastal water affects the metabolic rate of organisms and could reduce $\mathrm{Hg}^{2+}$ methylation rates by heterotrophic microorganisms. Methylation rates appear to be correlated with primary productivity. ${ }^{50}$ Consequently, less mercury, in the form of methylmercury, can be incorporated into this food chain. Furthermore, in the upwelling zones, methylmercury is converted into elemental mercury, leading to a supersaturation of the elemental species in surface waters. ${ }^{51}$

The highest mercury concentrations found in cutlassfish from the coastal areas that no suffer influence of upwelling events (Ilha Grande Bay and Guanabara Bay) can be explained by the fact that, in these areas, mercury methylation can take place both in the water column near the oxycline and in the sediment. ${ }^{52}$ The methylmercury formed in these places is transported to the mixed layer where it can be accumulated in the food chain. This accumulation can be observed in communities that live in sediments and in the water column, such as phytoplankton and zooplankton. ${ }^{51}$

In this study, Guanabara Bay (an eutrophic estuary) showed lower mercury concentrations than Ilha Grande Bay (an oligotrophic area). This fact can be explained by the high bioproduction (eutrophic conditions) found in this ecosystem, that generally has fish with low mercury-content. The reasons for this seem to be linked to a high fish growth rate in eutrophic waters and a high "biological dilution", in which a given mercury dose is spread throughout a large biomass. ${ }^{53}$

Despite the fact that T. lepturus specimens from Ilha Grande Bay and Guanabara Bay presented differences regarding mercury concentrations in their muscle tissue, they did not present significant differences in mercury accumulation pattern. A regression model demonstrated that when a logarithmic mercury concentration was related to T. lepturus length, the regression slopes of the equations were not significantly different for these areas (Ilha Grande Bay and Guanabara Bay) (Table 3). The linear regression of $\log$ mercury concentrations vs. total length (Table 3) showed that there are no differences in the rates of $\mathrm{Hg}$ accumulation between Ilha Grande Bay and Guanabara Bay. However, these rates of mercury accumulation are significantly different from Búzios coast.

Although no significant difference was found for selenium concentrations among the areas (Ilha Grande Bay, Guanabara Bay and Búzios coast), the linear regressions of log selenium concentration vs. total length (Table 3) showed that there are differences in the rates of selenium accumulation among these areas since the regression slopes of the equations were different for Ilha Grande Bay, Guanabara Bay and Búzios coast (Table 3).

Based on the results presented here, the regional differences in mercury behavior may be due to the fact that cutlassfish lives in ecosystems that present different environmental conditions (oligothophic, eutrophic and upwelling), pollution sources and food supplies.

Table 3. Relationships between logarithmic mercury and selenium concentrations ( $\mu \mathrm{g} \mathrm{g}^{-1}$ in dry wt.) in muscle tissue of cutlassfish and total length (L) in the three studied areas

\begin{tabular}{|c|c|c|c|c|}
\hline Sampling area & Trace element & Equation regression & $\mathrm{R}^{2}$ & $p$ \\
\hline \multirow[t]{2}{*}{ Ilha Grande Bay } & $\mathrm{Hg}$ & $\log [\mathrm{Hg}]=0.0007 \mathrm{~L}+1.78^{\mathrm{a}}$ & $\mathrm{R}^{2}=0.34^{\mathrm{a}}$ & $p<0.05$ \\
\hline & $\mathrm{Se}$ & $\log [\mathrm{Se}]=-0.0200 \mathrm{~L}+2.84$ & $\mathrm{R}^{2}=6.0 \times 10^{-4}$ & $p>0.05$ \\
\hline \multirow[t]{2}{*}{ Guanabara Bay } & $\mathrm{Hg}$ & $\log [\mathrm{Hg}]=0.0007 \mathrm{~L}+1.83^{\mathrm{a}}$ & $\mathrm{R}^{2}=0.60^{\mathrm{a}}$ & $p<0.05$ \\
\hline & $\mathrm{Se}$ & $\log [\mathrm{Se}]=-0.0007 \mathrm{~L}+3.06$ & $\mathrm{R}^{2}=0.11$ & $p>0.05$ \\
\hline \multirow[t]{2}{*}{ Búzios coast } & $\mathrm{Hg}$ & $\log [\mathrm{Hg}]=-0.0005 \mathrm{~L}+2.96$ & $\mathrm{R}^{2}=0.02$ & $p>0.05$ \\
\hline & $\mathrm{Se}$ & $\log [\mathrm{Se}]=-0.0022 \mathrm{~L}+3.10$ & $\mathrm{R}^{2}=3 \times 10^{-3}$ & $p>0.05$ \\
\hline
\end{tabular}

Significant $(p<0.05)$. 
Ilha Grande Bay and Guanabara Bay are two bay regions. The first one can be considered a non-contaminated area that presents typical oligotrophic environmental conditions, while the second one is a known contaminated area that presents eutrophic conditions, where known punctual sources of mercury exist. Búzios coast is an upwelling area that presents different environmental conditions throughout the year, mainly during the upwelling events.

\section{Selenium-mercury molar ratios}

In this study, all fish Se:Hg molar ratios were higher than 1 (surplus selenium). The mean molar Se:Hg ratios in cutlassfish from Búzios coast were higher $(22.49 \pm 15.19)$ than in cutlassfish from Ilha Grande Bay $(7.52 \pm 6.78)$ and Guanabara Bay (5.32 \pm 3.74$)$ (Table 2). A highly significant difference (Kruskal-Wallis ANOVA; $\mathrm{H}_{2,64}=20.04$; $\mathrm{p}<<0.001)$ was found in the $\mathrm{Se}: \mathrm{Hg}$ molar ratios among the sampling regions. Despite of cutlassfish from the three sampling regions presented similar muscular selenium concentration, T. lepturus from Búzios coast showed the highest Se:Hg molar ratio. This fact occurred due to the specimens from Búzios coast presented the lowest muscular mercury concentrations.

Ganther et al. ${ }^{5}$ first mentioned the Se:Hg molar ratio of $1: 1$ as protective against mercury toxicity in fish. Generally, marine fish species present the $\mathrm{Se} \mathrm{Hg}>1$ in muscle tissue. ${ }^{954}$ However, few data are available for tropical areas. ${ }^{9}$ The muscle tissue of two carnivorous fish species, Centropomus undecimalis (snook) and Micropogonias furnieri (croaker), from Guanabara Bay, presented Se:Hg molar ratio of 8.0 and 8.0, respectively. ${ }^{9}$ In our study, cutlassfish muscle samples also presented a considerable selenium excess in relation to mercury, demonstrating that the ratio between Se:Hg levels was of the same order of magnitude as those reported by Kehrig et al. ${ }^{9}$ If we consider that a molar ratio surplus of $\mathrm{Se} \mathrm{Hg}>1$ in fish might be sufficient to prevent mercury toxicity in the fish and the fish consumers, ${ }^{5}$ all samples would be considered suitable for consumption. ${ }^{4}$

\section{Conclusions}

Relatively low concentrations of trace elements were found in the muscle of cutlassfish when compared with other species from South America.

Based on the results presented here, it is possible to conclude that the biological characteristics (total length and/or size intervals) presented a significant influence on the muscular accumulation of mercury, whereas this pattern was not observed for muscular selenium accumulation.
Regional differences can be partly attributed to differences in the prevalent environmental conditions, and also to other factors, such as upwelling, that also influence trace element concentration in food web. Probably, differences in prey choices and availability across locations could be influence on the accumulation of mercury. However, a detailed study about the stomach contents of T. lepturus from these areas is needed to affirm this proposition. In addition, mercury and selenium concentrations and the $\mathrm{Se}: \mathrm{Hg}>1$ indicate that this fish species could be considered suitable for regular human consumption.

\section{Acknowledgements}

The authors would like to thank the financial support of the Fundação de Amparo à Pesquisa do Estado do Rio de Janeiro (FAPERJ, Proc 101976/2009), Coordenação de Aperfeiçoamento de Pessoal de Nível Superior (CAPES) and Conselho Nacional de Desenvolvimento Científico e Tecnológico (CNPq).

\section{Supplementary Information}

Supplementary material (map of Trichiurus lepturus sampling areas along the Rio de Janeiro State coast) is available free of charge at http://jbcs.sbq.org.br as PDF file.

\section{References}

1. Baeyens, W.; Leermakers, M.; Papina, T.; Saprykin, A.; Brion, N.; Noyen, J.; De Gieter, M.; Elskens, M.; Goeyens, L.; Arch. Environ. Contam. Toxicol. 2003, 45, 498.

2. World Health Organization (WHO); Environmental Health Criteria; World Health Organization: Geneva, 1989.

3. Belzile, N.; Chen, Y. W.; Gunn, J. M.; Tong, J.; Alarie, Y.; Delonchamp, T.; Can. J. Fish. Aquat. Sci. 2006, 63, 1; Yang, D.-Y.; Chen, Y.-W.; Gunn, J. M.; Belzile, N.; Environ. Rev. 2008, $16,71$.

4. Peterson, S.A.; Ralston, N. V. C.; Peck, D. V.; Sickle, J. V.; Robertson, J. D.; Spate, V. L.; Environ. Sci. Technol. 2009, 43, 3919.

5. Ganther, H. E.; Goudie, C.; Sunde, M. L.; Kopicky, M. J.; Wagner, P.; Oh, S. H.; Science 1972, 175(4026), 1122.

6. Reinfelder, J. R.; Fisher, N. S.; Luoma, S. N.; Nichols, J. W.; Wang, W.-X.; Sci. Total Environ. 1998, 219, 117.

7. Harris, R.; Kidd, K.; Shanley, J.; Environ. Pollut. 2008, 154, 1.

8. Seixas, T. G.; Kehrig, H. A.; Costa, M.; Fillmann, G.; Di Beneditto, A. P. M.; Secchi, E. R.; Souza, C. M. M.; Malm, O.; Moreira, I.; Environ. Pollut. 2008, 154, 98. 
9. Kehrig, H. A.; Palermo, E. F. A.; Seixas, T. G.; Branco, C. W. C.; Moreira, I.; Malm, O.; Estuar. Coast. Shelf Sci. 2009, 8 5,36 .

10. Branco, V.; Vale, C.; Canário, J.; Santos, M. N.; Environ. Pollut. 2007, 150, 373.

11. Kehrig, H. A.; Fernandes, K. W. G.; Malm, O.; Seixas, T. G.; Di Beneditto, A. P. M.; Souza, C. M. M.; Quim. Nova 2009, 32,1822

12. Costa, M. F.; Barbosa, S. C. T.; Barletta, M.; Dantas, D. V.; Kehrig, H. A.; Seixas, T. G.; Malm, O.; Environ. Sci. Pollut. Res. 2009, 16, 423.

13. Bittar, V. T.; Castello, B. F. L.; Di Beneditto, A. P. M.; Biotemas 2008, 21, 83 .

14. Martins, A. S.; Haimovici, M.; Palacios, R.; J. Mar. Biol. Ass. U.K. 2005, 85, 1223.

15. Bittar, V. T.; Di Beneditto, A. P. M.; Zoologia 2009, 26, 374.

16. Lacerda, L.D.; Pfeiffer, W.C.; Fiszman, M.; Cienc. Cult. 1981, 34, 921; Cardoso, A. G. A.; Boaventura, G. R.; Silva Filho, E. V.; Broad, J.; J. Braz. Chem. Soc. 2001, 6, 767.

17. Kehrig, H. A.; Malm, O.; Moreira, I.; Sci. Total Environ. 1998, 213, 263.

18. Creed, J. C.; Oliveira, A. E. S.; Pires, D. O.; Figueiredo, M. A. O.; Ferreira, C. E. L.; Ventura, C. R. R.; Brasil, A. C. S.; Young, P. S.; Absalão, R. S.; Paiva, P. C.; Castro, C. B.; Serejo, C. S. In Biodiversidade Marinha da Baía da Ilha Grande; Creed, J. C.; Pires, D. O.; Figueiredo, M. A. O., eds.; MMA/SBF: Brasília, 2007.

19. Jablonski, S.; Azevedo, A. F.; Moreira, L. H. A.; Braz. Arch. Biol. Technol. 2006, 49, 79.

20. Kjerfve, B.; Ribeiro, C. H. A.; Dias, G. T. M.; Filippo, A. M.; Da Silva Quaresma, V.; Cont. Shelf Res.1997, 17, 1609.

21. Valentin, J. L.; Tenenbaum, D. R.; Bonecker, A. C. T.; Bonecker, S. L. C.; Nogueira, C. R.; Villac, M. C.; Oecol. Bras. 1999, 3, 35.

22. Ikeda, Y.; Miranda, L. B.; Rock, N.; Bol. Inst. Ocean. Univ. S. Paulo 1974, 23, 33; Carbonel, C. A. A. H.; Cont. Shelf Res. 2003, 23, 1559.

23. Carbonel, C.; Rev. Bras. Ocean. 1998, 46, 1.

24. Barbieri, E. In Restingas: Origem, Estrutura, Processos; Lacerda, L. D.; Araújo, D. S. D.; Cerqueira, R.; Turcq, B., eds.; CEUFF: Niterói, 1984.

25. Silva, C. A.; Tessier, E.; Kütter, V. T.; Wasserman, J. C.; Donard, O. F. X.; Silva-Filho, E. V.; Braz. J. Ocean. 2011, 59, 259.

26. Moser, G. A. O.; Gianesella-Galvão, S. M. F.; Rev. Bras. Ocean. 1997, 45, 11.

27. Carbonel, C. A. A. H.; Valentin, J. L.; Ecol. Model. 1999, 116, 135.

28. US Environmental Protection Agency (US EPA); Guidance for Assessing Chemical Contaminant Data for Use in Fish Advisories; US Environmental Protection Agency: Washington DC, 1997.
29. Parsons, T.; Takahashi, M.; Hargrave, B.; Biological Oceanographic Process, 3 ed.; Pergamon: Oxford, 1984, p. 330.

30. Food and Agriculture Organization (FAO/SIDA); Manual de Métodos de Investigación del Medio Ambiente Acuático; FAO, 1983.

31. Kehrig, H. A.; Costa, M.; Moreira, I.; Malm, O.; J. Braz. Chem. Soc. 2006, 17, 1409.

32. Seixas, T. G.; Kehrig, H. A.; Di Beneditto, A. P. M.; Souza, C. M. M.; Malm, O.; Moreira, I.; J. Braz. Chem. Soc. 2009, 20, 243.

33. Håkanson, L.; Int. Rev. Ges. Hydrobiol. Hydrogr. 1994, 79, 621.

34. Kehrig, H. A.; Seixas, T. G.; Palermo, E. A.; Baêta , A. P.; Malm, O.; Moreira, I.; Quim. Nova 2011, 34, 377.

35. Valentin, J. L.; André, D. L.; Jacob, S. A.; Cont. Shelf Res. 1987, $7,77$.

36. Mol, J. H.; Ramlal, J. S.; Lietar, C.; Verloo, M.; Environ. Res. 2000, 86, 183.

37. Barbosa, S. C. T.; Costa, M. F.; Barletta, M.; Dantas, D. V.; Kehrig, H. A.; Malm, O.; Neotrop. Ichthyol. 2011, 9, 183.

38. Di Beneditto, A. P. M.; Souza, C. M. M.; Kehrig, H. A.; Rezende, C. E.; Mar. Biol. 2011, 158, 2209.

39. Di Beneditto, A. P. M.; Bittar, V. T.; Camargo, P. B.; Rezende, C. E.; Kehrig, H. A.; Arch. Environ. Contam. Toxicol. 2012, 62, 264.

40. Kehrig, H. A.; Brito Jr, J. L.; Moreira I.; Malm O.; RMZ Mat. Geoenviron. 2004, 51, 1099.

41. Kehrig, H. A.; Seixas, T. G.; Baêta, A. P.; Malm, O.; Moreira, I.; Mar. Pollut. Bull. 2010, 60, 2350.

42. Bisi, T. L.; Lepoint, G.; Azevedo, A. F.; Dorneles, P. R.; Flach, L.; Das, K.; Malm, O.; Lailson-Brito, J.; Ecol. Indic. 2012, 18, 291.

43. http://elegis.bvs.br/leisref/public/search.php accessed in July 2009.

44. Lemly A. D.; Environ. Monit. Assess. 2007, 125, 361.

45. Sfezer, P.; Domagala-Wieloszewska, M.; Warzocha, J.; Garbacik-Wesolowska, A.; Ciesielski, T.; Food Chem. 2003, $81,73$.

46. Fisher, N. S.; Reinfelder, J. R. In Metal Speciation and Bioavailability in Aquatic Systems; Tessier, A.; Turner, D. R., eds.; John Wiley \& Sons: Chichester, 1995.

47. Peters, G. M.; Maher, W. A.; Krikova, F.; Roach, A. C.; Jeswani, H. K.; Barford, J. P.; Gomes, V. G.; Reible, D. D.; Mar. Environ. Res. 1999, 47, 491.

48. Hamilton, S. J.; Sci. Total Environ. 2004, 326, 1.

49. Bargagli, R.; Monaci, F.; Sanchez-Hernandez, J. C.; Cateni, D.; Mar. Ecol. Prog. Ser. 1998, 169, 65.

50. Mason, R.; Fitzgerald, W. In Global and Regional Mercury Cycles: Sources, Fluxes and Mass Balances; Bayesens,W.; Ebinghaus, R.; Vasiliev, O., eds.; Kluwer Academic Publishers: Netherlands, 1996. 
51. Poissant, L.; Dommergue, A.; Ferrari, C. P.; J. Phys. IV 2002, 12(10), 143.

52. Rolfus K.; Fitzgerald, W.; Water, Air, Soil Pollut. 1995, 80, 291.

53. Björnberg, A.; Håtkanson, L.; Lundbergh, K.; Environ. Pollut. 1988, 49, 53.
54. Luten, J. B.; Ruiter, A.; Ritskes, T. M.; Rauchbaar, A. B.; Riekwel-Body, G.; J. Food Sci. 1980, 45, 416; Kaneko, J. N.; Ralston, N. V. C.; Biol. Trace Elem. Res. 2007, 119, 242.

Submitted: March 5, 2012 Published online: Junho 19, 2012 
Bioaccumulation of Mercury and Selenium in Trichiurus lepturus

Tércia G. Seixas, ${ }^{* a}$ Isabel Moreira, ${ }^{a}$ Olaf Malm ${ }^{b}$ and Helena A. Kehrig ${ }^{b}$

${ }^{a}$ Departamento de Química, Pontifícia Universidade Católica do Rio de Janeiro, 22453-900 Rio de Janeiro-RJ, Brazil

${ }^{b}$ Laboratório de Radioisótopos Eduardo Penna Franca, IBCCF,

Universidade Federal do Rio de Janeiro, 21941-902 Rio de Janeiro-RJ, Brazil

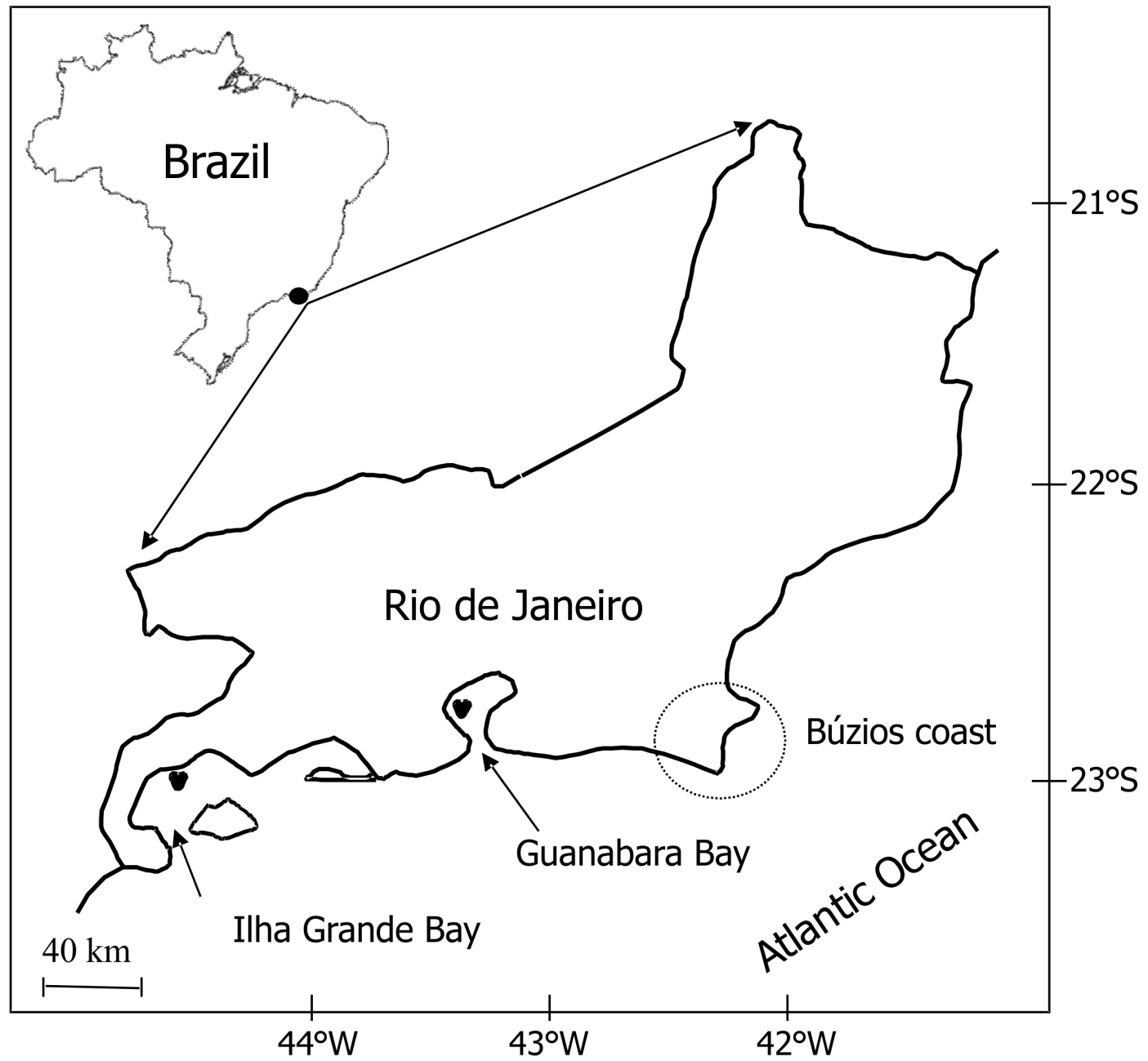

Figure S1. Trichiurus lepturus sampling areas along the Rio de Janeiro State coast. 